\title{
Военный министр А.Н. Куропаткин во Владивостокской крепости в 1903 г. (по новым источникам)
}

История поездки военного министра Российской империи А.Н. Куропаткина на Дальний Восток в 1903 г. изучена уже достаточно хорошо. Вполне ясны цель, задачи и общий характер поездки $[\mathbf{2}$, с. 69-91; 3, с. 132-140; 4, с. 91-98; 5, с. 19-40]. Неплохо описано и посещение военным министром Владивостока [1, с. 204-208], однако в этих исследованиях нет ни слова об осмотре А.Н. Куропаткиным непосредственно сооружений Владивостокской крепости. Причина заключается в том, что в отчёте о поездке министра на Дальний Восток, которым пользовались все без исключения исследователи, этих данных нет [7, с. 1-154]. Определённые сведения приводит в своих воспоминаниях подполковник барон А.П. Будберг, исполнявший в то время должность начальника штаба крепости [6, с. 284-289], однако для комплексного анализа взглядов А.Н. Куропаткина на состояние Владивостокской крепости накануне Русско-японской войны 1904-1905 гг. их явно недостаточно. Поэтому цель данной статьи - реконструировать на основе дневниковых записей А.Н. Куропаткина ход осмотра сооружений крепости, выявить его мнение об этих сооружениях и дать оценку высказанных им замечаний исходя из анализа развития Владивостокской крепости как во время Русско-японской войны 1904-1905 гг., так и после неё.

Владивостокскую крепость министр осматривал в два этапа: 12-15 и 24 мая, в промежутке между которыми он проинспектировал войска в районе зал. Посьета, побывал в зал. Де-Кастри, осмотрел на р. Амур укрепления г. Николаевск и стал первым и последним военным министром Российской империи, посетившим о. Сахалин [1, с. 204-208; 2, с. 69-91].

Поскольку никаких распоряжений со стороны министра о скромной встрече во Владивостоке, как это было сделано при посещении Хабаровска, не последовало, то по прибытии А.Н. Куропаткина 12 мая в 10 час. утра на железнодорожный вокзал его "встретили торжественно. Поднесли хлеб-соль. Представители китайцев, японцев и корейцев, каждые отдельно, поднесли по адресу. Были выведены все учебные заведения. Архиерей соборне встретил в соборе словом и молитвою" (РГВИА. Ф. 165. Оп. 1. Д. 1935. Л. 4) ${ }^{1}$. В 2 часа пополудни министр объявил всем собранным у ипподрома войскам Царские: привет и спасибо за службу. В строю было 4.464 чел. (РГВИА. Ф. 165. Оп. 1. Д. 1935. Л. 4).

Собственно объезд укреплений А.Н. Куропаткин начал только на следующий день, 13 мая, подробно фриксируя в дневнике свои впечатления от увиденного. Начал он с оборонительных сооружений, расположенных на п-ове Муравьёва-Амурского. "Объехал линию сухопутных укреплений; начиная с батареи Е (ныне редут 4) до моря и затем приморскую оборону от батареи № 15 на Петропавловский полуостров, бухту Диомид и батарею Голдобина.

Общее впечатление не благоприятно, ибо не вижу идеи в применении к местности. Садили укрепления и батареи там, где на местности это было выгодно, не связывая общею идеею то, что делали. Получилась разбросанность равнозначущих укреплений, вызывающая разбросанность сил, а силы, сравнительно с задачею, незначительные. Осталось мало выясненным, что главное, что второстепенное.

1 РГВИА - Российский государственный военно-исторический архив.

(C) Авилов Р. С., 2021

АВИЛОВ Роман Сергеевич, канд. ист. наук, старший научный сотрудник Института истории, археологии и этнографии народов Дальнего Востока ДВО РАН (ә. Владивосток). E-mail: avilov-1987@mail.ru 
Номенклатура укреплений тоже неудачная. Временными укреплениями называются, конечно, долговременные. Есть редуты. Есть фрорты № 1 и № 4, а 2 и 3 не существует и т.д." (РГВИА. Ф. 165. Оп. 1. Д. 1935. Л. 7-7 об.).

Несмотря на известную мелочность А.Н. Куропаткина, ошибки при фиксации увиденного начались с первых же строк. Так, упомянутые "батарея Е" и "Редут № 4", а точнее Саперный редут № 4 - это совершенно разные укрепления, хотя и располагавшиеся рядом. Во многом этому способствовала и номенклатура сооружений, которая действительно была далёкой от идеала, и в которой военный министр путался на протяжении всего визита. Сложилась она исторически, хотя и за сравнительно короткий срок. Временные укрепления и редуты на самом деле были малыми фортами, спроектированными на основе типового решения полудолговременного форта Буйницкого 1898 г., разработанного для второстепенных предмостных укреплений Передового театра военных действий (Польша), и принципиально ничем не отличались друг от друга. Но два таких укрепления были построены на месте полевых редутов, возведенных во время мобилизации Приамурского военного округа в 1895 г., и унаследовали их названия. В то же время во Владивостоке были три фрорта более сильной профили и более крупных по размеру, поэтому, чтобы опорные пункты обвода отличить от этих фрортов, их и назвали частично временными укреплениями, частично редутами. В целях унификации во избежание дальнейшей путаницы, вскоре по окончании Русско-японской войны 1904-1905 гг. все "укрепления", "редуты" и "люнеты" сухопутного обвода 1899 г. были переименованы в опорные пункты. Критика министром общей концепции крепости была вполне справедлива, хотя он и не упомянул, что имел к организации этой "разбросанности" прямое отношение.

Бросалась в глаза и проблема с артиллерийским вооружением крепости, которое, несмотря на наличие небольшого количества батарей вооружённых 10-дюйм. орудиями, оставалось "главным образом, устарелых образцов". Не понравилась министру и посадка батарей, где "замечается погоня за двумя зайцами. Пользуются слишком широко круговым обстрелом и ставят некоторые батареи так, чтобы они могли обстреливать оба входа в Босфор. В результате ни один из них не обстреливается достаточно сильно" (РГВИА. Ф. 165. Оп. 1. Д. 1935. Л. 7 об.). В этом его поддерживал начальник штаба Владивостокской крепости А.П. Будберг, который сам критиковал Токаревскую мортирную батарею за стремление её строителей дать возможность стрелять из мортир прямой наводкой по входу в прол. Босфор Восточный [6, с. 268].

Военный министр осмотрел значительную часть сухопутного обвода крепости: Батарею Ж, Сапёрный редут № 4, Форт № IV (Форт Суворова), Люнет № 3 и Временное укрепление № 3 (Форт Линевича). "Осмотр местности, - констатировал А.Н. Куропаткин, - убедил меня, что выбрана общая линия хорошо, но что вся местность такова, что представляет массу мёртвых пространств, что ближние обстрелы плохи.

Впереди выбранной линии лежат в 4 верстах командующие высоты с превышением до 80 сажен, кои и предполагалось включить в линию обороны, возведя на них форты № 2 и № 3. Но, независимо невозможности так растягивать линию, без очень значительного увеличения гарнизона, высоты эти большую часть лета покрыты туманом, имеют плохие ближние обстрелы и впереди их лежат ещё более командующие высоты. Даже занятие этих высот, как передовой позиции, может быть рекомендовано только для раскрытия сил противника, без упорной обороны" (РГВИА. Ф. 165. Оп. 1. Д. 1935. Л. 8-8 об.).

Проблема мёртвых пространств была подмечена верно, и её пришлось решать уже во время Русско-японской войны 1904-1905 гг. посредством возведения многочисленных полевых позиций в виде небольших групп окопов, хорошо применённых к местности. А вот на счёт туманов и господствующих высот военный министр уже явно выдавал желаемое за действительное. Туманы господствовали в июне и июле, в августе были редкостью, а всю остальную часть года с описанных высот открывался прекрасный вид на город и порт. Утверждение о том, что впереди высот, на которых не построили Форты II и III, лежат "более командующие высоты", не вполне соответствовало действительности. Высоты 431 м и 458 м являются абсолютно господствующими, 
а так называемая Синяя сопка (477 м) находится примерно в 20 км от этих высот и какого-либо серьёзного тактического влияния на них оказать не могла.

Вероятно, А.Н. Куропаткин сознательно искажал фракты, чтобы обосновать навязанную им местным инженерам оборонительную концепцию, отдающую ключевые высоты неприятелю без боя из соображений сокращения линии обороны с целью подогнать её под наличную, явно недостаточную, численность гарнизона крепости, и избавить себя от необходимости дальнейшей борьбы с министром финансов С.Ю. Витте за выделение новых кредитов на оборону российского Дальнего Востока. Впоследствии решение о сокращении длины сухопутного обвода крепости было признано ошибочным и новый сухопутный обвод Владивостокской крепости, основанный на опыте обороны Порт-Артура в годы Русско-японской войны 1904-1905 гг., был построен в 1910-1914 гг. именно на этих высотах, расположенных по южному борту долины р. Седанка.

Существующие укрепления показались А.Н. Куропаткину "довольно сильной постройки, достаточно обширны, рвы часто в скале, но оборона рвов не всюду достаточно надёжна, ибо часть тыльных рвов защищается с фрлангов открытых валов только стрелками" (РГВИА. Ф. 165. Оп. 1. Д. 1935. Л. 8 об.). Утверждение о "сильной постройке" являлось преувеличением, так как бетонные казематы укреплений могли выдерживать только обстрел из 6-дюйм. орудий и были недостаточно устойчивы к действию артиллерии более крупных калибров, что впоследствии и показал наглядно опыт осады Порт-Артура.

Несмотря на стремление присланного в 1899 г. А.Н. Куропаткиным из Петербурга во Владивосток военного инженера полковника К.И. Величко в максимальной степени учесть требования начальника по сокращению линии крепостного обвода, министр всё равно остался недоволен: "Общая ограда тоже дов[ольно] сильной профили, но фрланкируется только ружейным огнем с валов. Без постановки решёток или проволочных цепей - главная ограда слаба. Вообще вся линия слишком длинна" (РГВИА. Ф. 165. Оп. 1. Д. 1935. Л. 8 об., Л. 9).

Для усиления обороны он предложил несколько мер. Некоторые из них были вполне разумны, другие - совершенно не подходили для владивостокского рельедра.

1. "Образовать из форта № 1 и прилегающих к нему батарей опорный пункт, безопасный от атаки открытою силою. Назвать его фортом Муравьёвским. Иметь там самостоятельного коменданта, 2 роты пехоты, 1 роту артилл[ерии]. Иметь на несколько месяцев продовольственных запасов, усилить запасы артиллерийские. Иметь воду. Поставить задачею самостоятельно защищаться даже тогда, когда неприятель прорвется в других пунктах и овладеет Владивостоком. Роты надо назначить в составе гарнизона этого и других фортов полного состава в 200 чел., со всеми кашеварами и нестроевыми, вооружёнными" (РГВИА. Ф. 165. Оп. 1. Д. 1935. Л. 9-9 об.).

Проект был не так уж плох, но подходил только для равнинной местности. В условиях горы, на которой располагался форт и батареи, он был просто нереализуем при существовавших в то время технических возможностях. Очевидно, что без связи батарей с самим фортом подземными галереями, сообщение в дневное время с батареями было бы невозможно, равно как и вообще оборона склонов горы, за исключением самого форта - батареи группы Форта Муравьёва-Амурского хорошо просматривались с господствующих высот. Строительство же нормальной группы, способной надежно оборонять гору с Фортом Муравьёва-Амурского, потребовало бы средств, сопоставимых с ассигнованиями, выделяемыми на всю крепость. В действительности из положения вышли возведением полевых укреплений (групп окопов) севернее (впереди) форта, что ликвидировало мёртвые пространства на наиболее вероятном направлении атаки.

2. "Форт Суворовский надо обратить в такой же опорный пункт, вместе с окружающими его батареями. Сомкнуть все их общею оградою, так что самый фрорт, как и в форте Муравьёвском, должен будет служить цитаделью. Гарнизон тоже 2 роты пех[оты] и 1 рота артиллерии" (РГВИА. Ф. 165. Оп. 1. Д. 1935. Л. 9 об.). Мысль была правильная и впоследствии её частично даже реализовали, возведя полевые укрепления в виде групп окопов. Вообще 
же, укрепление в максимально возможной степени двух предложенных А.Н. Куропаткиным групп делало бессмысленным весь созданный К.И. Величко проект 1899 г. и отчасти было созвучно с идеями начальника штаба Владивостокской крепости барона А.П. Будберга - не размазывать бетон тонким слоем по всей линии обороны, а укрепить лишь тактически наиболее важные точки, но зато всерьёз [6, с. 264-275].

3. "Наконец укрепление № 3 тоже должно быть наименовано фортом и ему придан более самостоятельный характер. По местности этот форт будет иметь большое значение, ибо лежит ближе всего к вероятному сосредоточению морских сил противника и возможной высадки его. Местность допускает довольно скрытное приближение берегом. Г[енерал]-Л[ейтенант] Субботич предложил назвать его фортом Линевича. Охотно согласился. Надо хлопотать об этом, составив всепод[даннейший] доклад". Впоследствии именно так и поступили.

4. "Батареи № 13 и № 14 расположены хорошо. С высоты батареи № 15 казалось бы весьма желательным защищать самый вход в Босфор с мыса Басаргина, острова Скрыплёва и мыса Житкова. Но это очень удлиняет линию обороны. Поэтому вполне возможно ограничиться обороною более узкой части пролива против мыса Новосильского и Иродова" (РГВИА. Ф. 165. Оп. 1. Д. 1935. Л. 9 об.-10 об.). В первом случае речь шла о предположенных к постройке батареях Соболь и Басаргин, которых на момент визита А.Н. Куропаткина ещё не существовало. С батареи № 15, т.е. с Уссурийской батареи, необходимость вынести оборону входа в прол. Босфор Восточный на м. Басаргина, о. Скрыплёва и м. Житкова была видна более чем наглядно. Это и пришлось спешно делать уже после безнаказанного обстрела Владивостока 22 февраля 1904 г. японской эскадрой в ходе Русско-японской войны 1904-1905 гг. Это сделало все внутренние батареи почти бесполезными и привело к их частичному разоружению. Причём, если временная батарея 9-дюйм. мортир на о. Скрыплёва, установленная в 1905 г. там не прижилась, то в советское время на острове всё же построили противокатерную батарею № 101 на шесть 75-мм пушек Канэ [1, с. 218-237].

5. "Четыре батареи на мысе Иродова надо сомкнуть в отдельный район, поставив укрепление на перешейке, перекопав его и устроив ворота".

6. "Ворота должны быть устроены и в 3x фрортах".

7. "Батарею № 19, как встречную, в[есьма] желательно со временем образовать из 10 дюйм. орудий" (РГВИА. Ф. 165. Оп. 1. Д. 1935. Л. 10 об.). В действительности, с Назимовской батареей, о которой в данном случае идёт речь, поступили с точностью до наоборот. Четыре 11-дюйм. пушки с этой батареи сняли, вырубив даже закладные части из бетона, и переставили на батарею Соболь. На самой батарее, в виду потери ей боевого значения, остались только два 11-дюйм. орудия. Ни о каком перевооружении этой батареи 10дюйм. орудиями и речи потом даже не шло.

8. "Батареи на мысе Голдобина надо сохранить в их настоящем виде и вооружить..." (РГВИА. Ф. 165. Оп. 1. Д. 1935. Л. 10 об.). Уже в ходе Русско-японской войны 1904-1905 гг. эти батареи пришлось вообще разоружить за ненадобностью. Однако если на верхнюю (мортирную) батарею вернули 9 -дюйм. береговые мортиры, то 11-дюйм. береговые пушки с нижней батареи сняли навсегда и перенесли их на гору Воевода на Русском острове, модернизировав их станки. А на нижнюю батарею вернули когда-то уже стоявшие там 9-дюйм. береговые пушки на низких станках Семёнова. По состоянию на ноябрь 1914 г. батареи были не только разоружены, но даже их номера упразднили. Однако уже в советское время сооружения обеих батарей использовали для нужд вооружённой 120-мм/45 пушками Канэ противокатерной батареи № 924 , установленной на месте Голдобинской Нижней батареи.

Следующий день, 14 мая, А.Н. Куропаткин посвятил посещению Русского острова.

Первым фортификащионным сооружением, которое он здесь осмотрел, стала "Батарея на мысе "Новосильский" - расположена хорошо. Батарея Н[овосильцевская] нуждается в некоторой переделке. Необходимо, чтобы с неё можно было обстреливать самую прибрежную полосу (ближайшую). На батарее Новосильского тоже образуется мёртвое пространство. Необходимо на 
уступе ниже поставить два 6"2 орудия Канэ" (РГВИА. Ф. 165. Оп. 1. Д. 1935. Л. 11-11 об.).

Рекомендация А.Н. Куропаткина демонстрирует совершенное непонимание военным министром специфики современного ему морского боя или сражения приморской крепости с фрлотом. Артиллерийское состязание фрлота и крепости велось бы (как это и было впоследствии в Порт-Артуре) на больших дальностях огня, и наличие небольших мёртвые пространств у берега никакой роли бы не сыграло. Установка же двух орудий на тесный уступ, где располагалась прожекторная позиция батареи, во-вторых, привела бы к их открытому и скученному расположению и, как следствие, бессмысленной гибели при первом же серьезном обстреле неприятелем, а во-вторых, лишила бы батарею наиболее удобной позиции для расположения прожекторной станции, обеспечивающей возможность применения батареи в ночное время суток.

Далее был осмотрен Форт Поспелова (он же Временное укрепление № 4), который в дневниках называет то "Форт № 4", то "редут № 4": "Форт № 4 хорош. Ближние обстрелы требуют тщательной планировки. Не увлекаясь позициею на высоте 79, надо редут № 4 сомкнуть с морем солидными препятствиями в одну сторону с Босфором; в другую - с бухтою Новиком. Далее к югу, на о-в Русский не стоит и залезать" (РГВИА. Ф. 165. Оп. 1. Д. 1935. Л. 11 об.).

Последнее было явной ошибкой. Чтобы исправить допущенные А.Н. Куропаткиным и К.И. Величко в мирное время просчеты, на юг Русского острова пришлось срочно "залезать" уже во время Русско-японской войны 1904-1905 гг., тем более что имевшиеся там бухты на зиму не замерзали [1, c. 243-244]. При усилении Владивостокской крепости уже после войны с Японией, прежнее решение об оставлении беззащитным юга Русского острова, ключа Владивостокской крепости, было признано ошибочным, результатом чего стало строительство на острове 4 пехотных фортов, новых береговых батарей, а также большого количества противодесантных сооружений - артиллерийских капониров и полукапониров.

Осмотрев расположенные на о. Елена Ларионовские батареи, военный министр "прежде всего отметил настоятельную необходимость иметь через канал непрерывное сообщение. Надо устроить подъёмный мост. Переправа на одном пароме медленна, а для артиллерии при существующем пароме и опасна" (РГВИА. Ф. 165. Оп. 1. Д. 1935. Л. 12 об.). Любопытно, что эта мера всё-таки была впоследствии реализована, однако уже в позднее советское время, когда батареи на м. Ларионова по прямому назначению давно не использовались, а самого А.Н. Куропаткина более полувека не было в живых. На острове тогда располагался отряд радиоразведки, переправу через канал соорудили в виде поворотного пешеходного моста. Однако из-за дурной реконструкции канала (опять-таки советской), его берега были размыты и опоры моста перекосило. До настоящего времени этот мост не сохранился [8, с. 156$160 ; 311-318]$.

Немного запутавшись в Ларионовских батареях, А.Н. Куропаткин отметил в дневнике: "Батарея № 2 составлена из 6 или 8 сильных орудий Канэ [На самом деле - 8. - Р.А.]. Но она так приподнята над морем, что имеет только дальний обстрел.

Батарею № 1 из 8" орудий лучше оставить до замены их более сильными калибрами, но не 6 дюйм. старыми. Батарея № 3 расположена на двух терpacax по два 6" орудия на каждой. Батарея из 2-х орудий на нижней террасе имеет важное значение встречной батареи. Поэтому надо теперь же занять её двумя орудиями Канэ, сняв таковые с верхней батареи № 2. Батарея из двух 57 мил[лиметровых] орудий для защиты заграждений из мин слаба. Надо её довести до 6 орудий того же калибра" (РГВИА. Ф. 165. Оп. 1. Д. 1935. Л. 13).

С Батареями № 1 (Ларионовская Южная) и № 2 (Ларионовская на Пике) всё было указано верно, но упразднённую батарею Ларионовскую Уступную, на которой всё ещё сохранялись орудия, он перепутал с Батареей № 3 (Ларионовская Северная) и присвоил ей чужой номер, а о Ларионовской Северной вообще забыл. Замечания на счёт слишком высокого расположения батареи

2 Здесь и далее в цитатах знак " после калибра орудия означает "дюймовых". 
Ларионовская-на-Пике и мёртвых зонах в очередной раз свидетельствовали о недопонимании военным министром характера современного ему морского боя. Поэтому его предложение переместить два орудия на бывшую Уступную батарею, что уменьшило бы их обстрел, представляется неразумным. Реально оно выполнено не было. Двух 57-мм скорострельных пушек Норденфельда во взаимодействии с таковыми же с противоположного берега вполне хватало для контроля пролива. Впоследствии противоминную оборону в этом месте усилили двумя выкатными 3-дюйм. скорострельными пушками, разместив их в бетонном убежище. В советское время контроль входов в пролив осуществлялся из орудийных полукапониров на два 3-дюйм. горных орудия каждый, размещенных с двух сторон от обоих входов. Таким образом, увеличения количества орудий не произошло даже тогда.

Предложение военного министра "замкнуть Ларионовский полуостров в особый участок обороны", организовав оборону перешейка за каналом, на случай атаки его со стороны Поспеловских высот (РГВИА. Ф. 165. Оп. 1. Д. 1935. Л. 13-13 об.), последствий тоже не имело.

Большое внимание А.Н. Куропаткин уделил посещению горы Русских и осмотру расположенного на ней укрепления, которое он предложил назвать "Форт Русских": "При посещении был весь в тумане. Высота над уровнем моря 140 сажен. Дорога твёрдая, но с очень крутыми уклонами. Хорошему пехотинцу на подъём надо 45 мин. времени (от пристани в бухте Новик) [Имеется в виду современная пристань "Подножье". - Р.А.]. Форт в постройке. Ассигновано свыше 500/т[ыс]. руб. Главный недостаток - плохи ближние обстрелы и близость мёртвых пространств. Работы идут успешно. Рвы будут солидные. Но гласис со стороны дороги к пристани прорезан двумя зигзагами дороги, которые образуют готовые подступы в мёртвом пространстве. Надо особо организовать обстреливание этих подступов. Надо весьма тщательно планировать местность, дабы дать с форта сильный ближний огонь ружейный. В такой туман, в каком мы находились, позволяет подойти до рва без потерь. Необходимо, кроме рва, организовать препятствия. Надо соседние батареи взять с фортом в один общий обвод. Устроить непрерывную ограду, примкнув таковую к форту и всё это укрепление из форта и двух батарей окружить проволочною сетью, оставив лишь выходы и мало того, усилить, по мысли на[чальни]ка крепостного инженер[ного] управления полковника Джигалковского (очень дельного, энергичного и способного инженера) небольшими фругасами. Форт Русский будет обеспечен водою. Надо обеспечить его продовольствием и боевыми запасами. Посетили казематиров[анную] казарму на роту крепостной артиллерии в 200 чел. Сыра. Электрич[еское] освещение" (РГВИА. Ф. 165. Оп. 1. Д. 1935. Л. 13 об. -14 об.).

Начальником инженеров Владивостокской крепости и Строителем Владивостокских укреплений был военный инженер В.И. Жигалковский. Указанные военным министром недостатки форта отмечало и командование крепости. Начальник её штаба А.П. Будберг писал: "Форт на Русской Горе представлял из себя весьма курьёзное фортификационное сооружение; скаты горы были так круты, что для их обстрела защитникам надо было вылезать на передний гласис и высовываться вперёд; вершина горы очень часто была закутана туманом; в середину форта была всунута батарея из четырёх старых 6-дюймовых пушек на морских установках, назначенных для обстреливания бухт острова, очень многочисленных, обширных и на 90\% с горы не видных; вообще, в военном отношении это была очень дорогая по стоимости фортификационная нашлёпка, но никак не сколько-нибудь сообразное оборонительное сооружение. Тем не менее оно пользовалось большой известностью и неизменно включалось в число пунктов, куда возили высокое начальство и знатных гостей; быть во Владивостоке и не побывать на Русском форту и не полюбоваться открывавшимся оттуда видом на оба залива, на Босфор Восточный и на разбросанные по нему острова считалось невозможным" [6, с. 270]. Идея насчёт проволочной сети была вполне разумной, а мысль о соединении двух соседних батарей в общий обвод с фортом хотя и представляла интерес, но требовала слишком больших трудозатрат.

Последними фортификационными сооружениями, осмотренными в этот день министром, уже по возвращении на п-ов Муравьёва-Амурского, стала расположенная на его оконечности (п-ов Шкота) группа из двух Токаревских 
батарей: "Внизу из 9 дюйм. орудий Морского ведомства. По формулярам они уже окончили свою службу и могут дать нам, как докладывал Комендант лишь на 10 выстрелов. Значение батареи большое: встречный огонь при прорыве. Надо скорее её перевооружить, если можно, то тоже 9 или даже 10" орудиями. Верхняя Токаревская батарея из 8-11" мортир очень сильная батарея с круговым обстрелом. Окончена. [Н.И.] Холодовский [в 1903-1904 гг. - помощник начальника артиллерии Приамурского военного округа. - Р.А.] однако справедливо заметил, что мортиры слишком мало прикрыты. Надо прибавить на бетон хороший слой земли. Прежде из этих мортир ожидали и прицельный огонь. Хранилище для снарядов есть" (РГВИА. Ф. 165. Оп. 1. Д. 1935. Л. 14 об. -15$)$.

Первая из упомянутых батарея не имела номера, но орудия на ней сохраняли до конца Русско-японской войны 1904-1905 гг. Куропаткин не обратил внимания, что рядом с ней находилась батарея Токаревская Нижняя, вооруженная 57-мм скорострельными пушками Норденфельда, чего было вполне достаточно для защиты входа в пролив от проникновения мелких судов. Никакая 10-дюйм. батарея там не была нужна, и её так и не построили. Что касается второй батареи, то А.Н. Куропаткин правильно отметил недостаточную защиту мортир, связанную с тем, что от них ожидали ещё прицельный огонь, как о том писал и начальник штаба крепости А.П. Будберг, хотя слой земли не являлся решением проблемы. Более того, военный министр упустил, что бетоном была прикрыта только половина орудий батареи (правая полубатарея), а орудия левой полубатареи, хотя и стояли на бетонных основаниях, но бетонных брустверов вообще не имели.

15 мая А.Н. Куропаткин продолжил объезд оборонительной линии на материке от Форта графа Муравьёва-Амурского до моря. Форт вызвал у него смешанные чувства, поскольку "занимает очень сильную позицию, но в настоящем виде не силён. Есть участки со рвами без каменных одежд. Надо фрорт № 1 взять в общую ограду с батареями а, б, г. Усилить всё это рвом и местными преградами. Получится опорный пункт значительной силы" (РГВИА. Ф. 165. Оп. 1. Д. 1935. Л. 17). Вывод этот был верен лишь отчасти, поскольку окапывать всё непрерывной оградой в виде рва и вала было бы дорого, и не имело большого смысла. Тем не менее рациональное зерно в идее присутствовало. Вероятно, А.Н. Куропаткин смог до некоторой степени почувствовать то, чего не понял посланный им во Владивосток К.И. Величко, - что классические равнинные формы долговременной фортификации во Владивостоке не применимы в принципе.

Люнет № 2, по мнению министра, был расположен хорошо, но не силён. Укрепление № 1 - "очень сильно, но надо его доделать... В особенности в нём при массе бетонных работ, слабы рвы. Надо местные преграды впереди". Сила укрепления, способного выдержать лишь обстрел 6-дюйм. артиллерией, была А.Н. Куропаткиным явно преувеличена. "Люнет № $1,-$ продолжал он, - ближайший к морю, должен быть обращён в самостоятельное сомкнутое укрепление, безопасное от атаки открытою силою. Надо усилить решётками или проволокою. Участок непрерывной ограды между люнетом и морем имеет во рву контр-эскарп, обстреливаемый из полукапонира только в восточной половине. Надо создать такую же оборону и в западной. Для сего, надо всю западную часть до железной дороги эскарпировать и поставить второй полукапонир. За линию железной дороги на участке до моря необходимо поставить блокгауз (бетонный), из которого весь пляж в обе стороны мог бы обстреливаться" (РГВИА. Ф. 165. Оп. 1. Д. 1935. Л. 17-18).

Описанный короткий участок ограды между Укреплением № 1 и Люнетом № 1, действительно обстреливался из капонира Укрепления № 1, но никаких других капониров и полукапониров там не было. Что касается блокгауза, то он действительно был построен, правда, в деревянном исполнении и уже во время Русско-японской войны 1904-1905 гг.

Не самое благоприятное впечатление на министра произвели и береговые батареи: "Все их нашёл совершенно незащищёнными от атаки открытою силою с моря. Просил все осмотренные мною батареи сомкнуть с горжи, дать им пехотное прикрытие и ограждение проволокою или решётками" (РГВИА. Ф. 165. Оп. 1. Д. 1935. Л. 18). Рекомендация имела определённый смысл, поскольку Амурский залив зимой замерзал. Это делало возможной пехотную 
атаку берегового фронта Владивостокской крепости прямо со льда. Частично это пожелание даже было реализовано, например, на Безымянной Батарее.

Батарею из четырёх 10-дюйм. орудий он признал необходимым оставить на занимаемом ею месте. "Место южнее, предположенное для постройки новой батареи и переноса туда $10 "$ орудий хорошо, но надо ставить туда $10 "$ новые орудия, не трогая уже установленных. Установку на этой батарее (существующую) надо исправить и дать круговой обстрел" (РГВИА. Ф. 165. Оп. 1. Д. 1935. Л. 18-18 об.). Эти рекомендации оказались не только разумными, но и полностью совпали с мнением местного командования, поэтому впоследствии были выполнены в точности.

В первом часу ночи на 16 мая А.Н. Куропаткин со свитой покинул крепость, отправившись на крейсере "Новик" инспектировать войска в районе зал. Посьета. Вернулся он в тот же день и уже 17 мая отправился на крейсере "Аскольд" в зал. Де-Кастри (РГВИА. Ф. 165. Оп. 1. Д. 1935. Л. 22 об., 31).

Общие замечания по Владивостокской крепости военный министр подготовил как раз в это время, т.е. до возвращения и осмотра оставшихся береговых батарей. Он пришёл к следующим выводам: "Общее протяжение сухопутной и морской обороны составляет свыше 40 вёрст. Сухопутная северная линия имеет 10 вёрст. На острове Русский сухопутная оборона на двух участках составляет 7 вёрст. Морские батареи расположены по растянутым линиям и близ пунктов, удобных для высадки. Батареи не защищены с тыла. Предприимчивый противник может, пользуясь туманом, или темнотою сделать высадку против приморских батарей со стоны каждого из заливов.

Дабы оборона не была слишком разбросанною, необходимо определить следующие важнейшие районы для обороны и потребные для них силы:

А. С сухого пути на северный фронт.

1) Форта Муравьёвского

2) Редута № 1

Редута № 2 и 3

Форта Суворовского

Форта Линевича

Промежуточные форты № 4, 5, 6 и 7

2 рот[ы]

$1 \mathrm{p}$ [ота]

$1 \mathrm{p}$ [ота]

2 р[оты]

2 р[оты]

2 р[оты]

В. С сухого пути на остров русский

1) Форт русский

2) редут № 8 и вся линия между Босфором Восточным и линиею

10 poт.

3) Оборона полуострова Ларионовского

2 р[оты]

2 роты

1 p. $^{3}$

В) Для охранения приморской стороны:

Итого 4

1) От форта Линевича

до Петропавловского полуострова, включительно 2 роты

2) От редута № 1 до мыса Токаревского 5 рот.

3) Охрана полуострова Ларионовского 1 рота

В частных резервах

1) За северною сухопутною линиею

2) На острове Русский

3) На приморской обороне

\begin{tabular}{l}
\hline 8 рот \\
6 рот. \\
2 \\
2 \\
\hline 10 р[от]
\end{tabular}

В общем резерве

От 4-х до 8 бат[альо]нов

16-32 роты.

Итого, считая минимально, приходится назначить:

1) Для обороны сухопутных укреплений 14 рот, в частном резерве за ними 8 рот, итого

22 роты.

3 Выделенный курсивом фрагмент текста зачеркнут в дневнике рукой самого А.Н. Куропаткина. 
2) Для охраны приморских линий обороны -8 рот и в частном резерве за ними - 2 , итого

3) В общем резерве 4 бат[альона]

10 рот.

16 рот.

\section{8 [рот]}

Всего для минимального занятия Владивостока надо 12 батальонов. Имеем мы только 6. Отсюда очевидна необходимость разворачивать существующие 6 бат[альо]нов в военное время в 12, к чему и надо стремиться. Время будет достаточно. Ибо, если бы на Владивосток напали ранее увода полевых войск в Маньчжурию, то мы поможем из Никольска полевыми войсками. Если же нападут после увода, то будет достаточно времени, чтобы мобилизоваться. Кроме того необходимо подготовить формирование 4-х дружин из жителей и моряков. В наступающее пятилетие желательно провести всю эту меру, но в крайности надо увеличить при мобилизации с 6ти бат[альо]нов до 8, т.е. доформировать по одному бат[альо]ну на полк. Теперь же надо перевезти во Владивосток и хранить в нём 4.000 бердановских ружей и патронов к ним для вооружения дружин и дополнительных запасных, кои будут во Владивосток присланы, сколько помню, в числе 4.000 человек.

Наиболее крепко занять и упорно оборонять надо все фрорты и редуты № 1 и № 7 и № 8. Эти пункты считаю главнейшими" (РГВИА. Ф. 165. ОП. 1. Д. 1935. Л. 26 об.-29).

Поскольку война с Японией началась заметно раньше, чем ожидали в Военном министерстве, практически все эти рекомендации так и остались на бумаге, а те немногие, что реализовывались на практике, осуществлялись по распоряжениям командования крепости уже непосредственно во время войны. Определённая А.Н. Куропаткиным как необходимая численность гарнизона в 12 батальонов в военное время оказалась впоследствии недостаточной - к моменту окончания войны в крепости было уже 60 тыс. чел. личного состава [1, c. 273]. Что же касается последнего из процитированных абзацев, то понять его смысл невозможно в принципе, поскольку редутов с такими номерами в крепости не было, равно как и "промежуточных фортов". Генерал-адъютант А.Н. Куропаткин сам придумал какую-то новую номенклатуру, которая никогда не была принята, и пользовался ей, запутав всех и сделав решительно непонятным, какие пункты он считал "главнейшими". Это наглядно показывает насколько министр был внимателен при ознакомлении с крепостью, и воспринимал всё то, что так старались донести до него комендант крепости генерал-лейтенант Д.Н. Воронец ("Комендант ещё не опытен и недостаточно авторитетен, но очень работящ и принялся за дело изучения крепости горячо. Слишком нервен") и начальник штаба крепости подполковник А.П. Будберг ("способный и энергичный") (РГВИА. Ф. 165. Оп. 1. Д. 1935. Л. 29 об.-30).

Мнение А.Н. Куропаткина об А.П. Будберге представляет большую ценность, особенно с учётом того, что сам начальник штаба Владивостокской крепости был крайне разочарован визитом военного министра во Владивосток и дал ему предельно нелицеприятную характеристику: "Все его замечания и поучения показывали, что он был чрезвычайно ограниченным миниатюристом военного дела; он очень хорошо разбирался в разных второстепенных деталях укреплений и в мелочных вопросах, но становился слепым и тупым во всём, что касалось широкого взаимодействия различных фракторов обороны местности и т.п." [6, с. 286]. А поскольку во взглядах на начальника артиллерии крепости полковника И.П. Климова они сошлись, то с высокой долей вероятности и А.П. Будберг оказался честным мемуаристом, и А.Н. Куропаткин в своих дневниках не лукавил. Так, военный министр констатировал, что полковник Климов "никуда не годный пьяница" (РГВИА. Ф. 165. Оп. 1. Д. 1935. Л. 30), а начальник штаба крепости, что "Командиром крепостной артиллерии был полковник Климов, вегетарианец, непротивленец, временами запойный пьяница; отличался тем, что ходил из Управления (на Эгершельде) на Чуркин пешим порядком кругом всей бухты и вечно жевал какие-нибудь овощи, которыми были набиты его карманы" [6, с. 280]. Полковника В.И. Жигалковского, талантам которого отдавал должное и А.П. Будберг, и военный инженер П.П. Унтербергер, вообще считавший его гением, военный министр характеризовал как "совсем выдающегося инженера" (РГВИА. Ф. 165. Оп. 1. Д. 1935. Л. 30). 
Впрочем, в самой крепости тоже хватало упущений, что не ускользнуло от взгляда министра: "Весьма плохо, что в крепости до сих пор нет мобилизационного плана. Никто не знает своих обязанностей. Ещё страннее, что в крепости не имеется крепостных запасов, под предлогом, что на текущее довольствие всегда хранится продовольствие в годичной пропорции. Шпионов в крепости должно быть достаточно, особенно японцев. Между тем личный персонал кр. Владивосток хорош". Он настаивал, что "в составе гарнизона необходимо сохранить конную команду из креп[остных] полков, доведя её до 160 человек. Кроме усиления гарнизона надо продвигать вперёд артил[лерийское] вооружение и притом в соответствии с готовностью инженерною. Считать орудие доставленным лишь при доставке и снарядов, и зарядов к нему.

По инженерной части обратить особое внимание на приведение в неприступный от атаки открытою силою вид всех намеченных фортов и редутов № 1 , № 7 и № 8 .

Войскам надо обеспечить несколько большую подвижность. Необходимо постепенно придать им некоторое число обозов. Особенно надо иметь хотя на 2 роты одну походную кухню. Часть кухонь имеется.

Для передвижения по городу и окрестностям необходимо проделать ещё некоторое число военных дорог, а в существующих на некоторых участках надо уклоны сделать более доступными. Войскам необходимо обеспечить хорошую питьевую воду, что не всюду достигнуто. Для офицеров необходимо поспешить устройством более обширного чем ныне военного собрания" (РГВИА. Ф. 165. Оп. 1. Д. 1935. Л. 29-31).

Вернувшись 24 мая во Владивосток, А.Н. Куропаткин успел до отъезда в Японию осмотреть ещё несколько береговых батарей, объектов крепостной инфраструктуры, крепостное артиллерийское управление и штаб. По итогам посещения Иннокентьевской батареи на 6 6-дюйм. пушек Канэ, он записал в дневнике: "Очень хорошо расположена. Но очень и видна с моря. Подбить орудия большого труда не составит. Надо принять все меры к маскированию ея. Надо также сделать её безопасною от атаки открытою силою". Упраздненную батарею на м. Купера он предложил обратить "в редут для пехотного прикрытия приморской батареи и связать в одно укрепление с нижней Куперовской батареею". Более всего ему понравилась "Проектируемая Госпитальная батарея (№ 6). Отлично выбранное место, хороший обстрел на оба прохода. Необходимо поставить здесь 4 - 10" орудия, которые уже следуют во Владивосток в числе $8^{4}$. Остальные 4 орудия надо поставить на батарею № 17 (вместо 9й). Наконец вопрос о том, чтобы выстроить батарею № 14, но вооружить её вместо предположенных мортир $4-10 "$ орудиями, предоставить обсуждению местного начальства. Если будет решено в пользу 10" орудий, то таковые или могут быть назначены вновь, или, в крайности, сняты с Сапёрной батареи и заменены там 11" или даже 9", снятыми с батареи № 17" (РГВИА. Ф. 165. Оп. 1. Д. 1932. Л. 1-1 об.).

Несмотря на рекомендации министра, Батарея № 17 сохранила своё застарелое вооружение в виде 9-дюйм. пушек на низких станках Семёнова. Ставить туда новейшие 10-дюйм. орудия было нерациональным, поскольку у них был бы стеснён обстрел. Более того, А.Н. Куропаткин не знал или забыл, что упомянутые им 9-дюйм. орудия были на низких станках, и без коренной модернизации их нельзя было бы установить на Сапёрную батарею. При этом Батарея № 14 (батарея Басаргин) действительно была вооружена новейшими 10-дюйм. орудиями, которые имели с той позиции прекрасный обстрел.

На Голдобинскую пушечную батарею на 4 11-дюйм. орудия его взгляды с крепостным начальством тоже разошлись. Если министр полагал, что батарея "очень хорошо расположена; хорошо маскирована и её надо сохранить (РГВИА. Ф. 165. Оп. 1. Д. 1932. Л. 1 об.-2), то во Владивостоке считали, что реально столь мощные орудия там не нужны. В итоге, их переставили на Русский остров на гору Воевода, а вместо них установили те самые 4 старых 9-дюйм. береговых орудия на низких станках. В советское время на эту же позицию установили противокатерную батарею № 924 на четыре 120-мм/45 пушки Канэ.

4 Кажется, в числе 6, а 6 уже есть. - Прим. док. Эта батарея так и не была достроена (Прим. Р.А.) 
Таким образом, разделы дневника А.Н. Куропаткина, посвящённые посещению им Владивостокской крепости, свидетельствуют, что он, безусловно, обладал хорошим военным глазомером, огромным опытом, и мог замечать не только хозяйственно-бытовые мелочи из жизни войск. Его замечания, касающиеся Владивостокской крепости, представляются во многом довольно разумными. Видимо, он достаточно внимательно слушал, что ему говорили А.П. Будберг и В.И. Жигалковский, о которых он отозвался в самой превосходной степени. Однако во многих случаях у него был явный приоритет бюрократических соображений и личных амбиций над военными. Он сразу высоко оценил выбранные позиции будущих батарей Соболь и Басаргин, которых так не хватало в начале Русско-японской войны 1904-1905 гг., вполне разумно рекомендовал сразу поставить там 10-дюйм. батарею, поддержал переделку Сапёрной батареи под круговой обстрел, советовал усилить маскировку береговых батарей. Уже на местности он сразу понял недостатки проекта военного инженера К.И. Величко, к созданию которого сам приложил руку - плохой обстрел с укреплений, вызванный сложнейшим рельефом местности и равномерное размазывание бетона тонким слоем вдоль оборонительного обвода без выделения главного и второстепенного. Его рекомендация о превращении Фортов I и IV, которые он назвал "Муравьёвским" и "Суворовским", в сильные опорные пункты группового характера могла бы существенно изменить конфигурацию крепости, если бы это было сделано с самого начала и реализовано должными техническими средствами.

Вместе с тем желая замаскировать главный просчет составителей проекта крепости, которые были связаны директивой, данной самим военным министром - оставление подковообразной группы высот у р. Седанка, господствующих над крепостью, в руках неприятеля - он пошёл на сознательный подлог. Впереди этой группы возвышенности каких-либо господствующих над ней высот не было, расположенная у основания п-ова Муравьёва-Амурского Синяя Сопка (477 м) была расположена слишком далеко и за несколькими линиями возвышенностей, и не могла оказывать какого-либо тактического влияния на оборонительный обвод крепости, включая и расположенные впереди него высоты. Он явно преувеличивал силу возведённых по проекту 1899 г. сухопутных укреплений, которые реально могли выдерживать лишь обстрел из 6-дюйм. орудий и имели мало казематированных помещений. В дневнике можно проследить явную отсталость А.Н. Куропаткина в вопросах организации береговой артиллерийской обороны, когда он предлагает в узкостях, где заведомо ограничен обстрел, ставить т.н. "встречные" батареи вооружённые современными длинноствольными дальнобойными орудиями, такими как 10дюйм. береговые пушки на лафретах Дурляхера и 6-дюйм. пушки Канэ, ограничивая их возможное боевое использование, хотя именно там вполне достаточно было сделать то, что уже и сделали - поставить 57-мм скорострельные пушки Норденфельда. То же самое касается его боязни небольших мёртвых пространств, остающихся у берега при постройке батарей, имеющих широкий дальний обстрел.

Вызывает недоумение и повышенное внимание А.Н. Куропаткина к вопросам номенклатуры фортификационных сооружений. Он сразу же ломает существующую нумеращию фортов, предусматривавшую возведение во вторую очередь фрортов на незанятых в то время господствующих высотах, даёт звучные патриотически-звучащие названия номерных фортов, переклассифицирует в фрорты два временных укрепления, выполняющие более или менее самостоятельные задачи, и в заключение начинает именовать промежуточные опорные пункты какими-то "редутами" и "промежуточными фрортами", вводя нумерацию и названия, которые потом никогда не появились ни на картах, ни в документах, и именно по этой, никому не понятной (в том числе и ему самому) системе названий и номеров, он и делает расчёт войск, необходимых для занятия оборонительной линии, превращая свои рекомендации в полнейшую бессмыслицу.

Путаница с Ларионовскими батареями наглядно показывает, что к поездке он явно не подготовился, проявив очевидное легкомыслие, отказавшись просмотреть письменные материалы, предоставленные ему командованием крепости. Главная же беда А.Н. Куропаткина, имевшего огромный опыт и знания в области военного дела и, в целом, неплохо в нём разбиравшегося, 
состояла в том, что военно-бюрократические и карьерные соображения, амбиции и собственные сиюминутные капризы он ставил выше, чем соображения профрессиональные, т.е. интересы дела. Это вполне подтверждается сохранившимися материалами о его посещении Владивостокской крепости.

\section{Литература}

1. Авилов Р.С., Аюшин Н.Б., Калинин В.И. Владивостокская крепость: войска, фортификация, события, люди. Ч. І. "Назло надменному соседу". 1860-1905 гг. Владивосток: Дальнаука, 2013. 383 с.

2. Авилов P.С. Военный министр Алексей Николаевич Куропаткин на о. Сахалине (1903 г.) // Вестник Сахалинского музея. 2020. № 1. С. 69-91.

3. Авилов Р.С. "Для охранения границ Южно-Уссурийского края сформировать..." История создания и службы регулярной кавалерии на Дальнем Востоке России (1869-1914 гг.). Владивосток: Дальнаука, 2011. 181 с.

4. Авилов Р.С. Дневник военного министра А.Н. Куропаткина по поездке на Дальний Восток в 1903 г. и его значение: опыт анализа и подготовки к публикации // Шестые архивные научные чтения имени В.И. Чернышевой: Материалы всерос. науч.-практ. конф. "Дальний Восток России: от прошлого - к будущему". Хабаровск: ООО "Амурпринт", 2020. С. 91-98.

5. Авилов Р.С. Поездка военного министра А.Н. Куропаткина на Дальний Восток в 1903 г. - Владивосток, Порт-Артур, Япония - и её результаты // Юридическая наука: история и современность. 2019. № 3. С. 19-40.

6. Будберг А.П., барон. Сибирские воспоминания / Ред.-сост., комментарий Р.С. Авилов, В.И. Калинин; вступ. ст. Р.С. Авилов, Н.Б. Аюшин, В.И. Калинин. Владивосток: ОИАК-ПКРО РГО, 2017. 434 с.

7. Отчёт Военного Министра по поездке на Дальний Восток в 1903 г. Ч. 1. Осмотры войск, военных учреждений и заведений. СПб.: Военная типография, 1903. 154 с.

8. Стратиевский О.Б. Остров Русский (страницы истории). Владивосток: Дальнаука, 2013. 488 с.

\section{Транслитерация по ГОСТ 7.79-2000 Система Б}

1. Avilov R.S., Ayushin N.B., Kalinin V.I. Vladivostokskaya krepost': vojska, fortifikatsiya, sobytiya, lyudi. CH. I. "Nazlo nadmennomu sosedu". 1860-1905 gg. Vladivostok: Dal'nauka, 2013. 383 s.

2. Avilov R.S. Voennyj ministr Aleksej Nikolaevich Kuropatkin na o. Sakhaline (1903 g.) // Vestnik Sakhalinskogo muzeya. 2020. № 1. S. 69-91.

3. Avilov R.S. "Dlya okhraneniya granits YUzhno-Ussurijskogo kraya sformirovat'..." Istoriya sozdaniya i sluzhby regulyarnoj kavalerii na Dal'nem Vostoke Rossii (1869-1914 gg.). Vladivostok: Dal'nauka, 2011. $181 \mathrm{~s}$.

4. Avilov R.S. Dnevnik voennogo ministra A.N. Kuropatkina po poezdke na Dal'nij Vostok v 1903 g. i ego znachenie: opyt analiza i podgotovki k publikatsii // SHestye arkhivnye nauchnye chteniya imeni V.I. CHernyshevoj: Materialy vseros. nauch.-prakt. konf. "Dal'nij Vostok Rossii: ot proshlogo - k budushhemu". KHabarovsk: OOO "Amurprint", 2020. S. 91-98.

5. Avilov R.S. Poezdka voennogo ministra A.N. Kuropatkina na Dal'nij Vostok v 1903 g. - Vladivostok, Port-Artur, YAponiya - i eyo rezul'taty // YUridicheskaya nauka: istoriya i sovremennost'. 2019. № 3. S. 19-40.

6. Budberg A.P., baron. Sibirskie vospominaniya / Red.-sost., kommentarij R.S. Avilov, V.I. Kalinin; vstup. st. R.S. Avilov, N.B. Ayushin, V.I. Kalinin. Vladivostok: OIAKPKRO RGO, 2017. 434 s.

7. Otchyot Voennogo Ministra po poezdke na Dal'nij Vostok v 1903 g. CH. 1. Osmotry vojsk, voennykh uchrezhdenij i zavedenij. SPb.: Voennaya tipografiya, 1903. $154 \mathrm{~s}$. $488 \mathrm{~s}$.

8. Stratievskij O.B. Ostrov Russkij (stranitsy istorii). Vladivostok: Dal'nauka, 2013. 
Авилов Р. С. Военный министр А.Н. Куропаткин во Владивостокской крепости в 1903 г. (по новым источникам).

В статье на впервые вводимых в научный оборот материалах Российского государственного военно-исторического архива (РГВИА), исследуется история посещения Владивостокской крепости военным министром Российской империи А.Н. Куропаткиным в 1903 г. Министр посетил крепость в рамках своей поездки по Дальнему Востоку. В статье описывается ход осмотра им фортификационных сооружений, анализируются сделанные им замечания и рекомендации. Даётся оценка степени влияния его рекомендаций на дальнейший ход оборонительного строительства во Владивостоке.

Ключевые слова: Приалурский военный округ, Владивостокская крепость, А.Н. Куропаткин, Русско-японская война 1904-1905 г2., Дальний Восток России, русская арлия.

Avilov R. S. The War Minister Aleksey N. Kuropatkin in Vladivostok Fortress in 1903 (using a new sources).

Using the unpublished documents of Russian State Military Historical Archive (RSMHA), the article investigates the history of visit to Vladivostok Fortress in 1903 by the War Minister of Russian Empire Aleksey N. Kuropatkin. He visited the Fortress during the voyage in a Far East. The article describes how he inspected the fortifications, and analyzes his criticism and recommendations. It is noted the value of his recommendations to the further defensive construction progress in Vladivostok.

Key words: Priamurskiy Military District, Vladivostok Fortress, Aleksey N. Kuropatkin, Russo-Japanese War of 1904-1905, Russian Far East, Russian Army.

Для цитирования: Авилов Р. С. Военный министр А.Н. Куропаткин во Владивостокской крепости в 1903 г. (по новым источникам) // Ойкумена. Регионоведческие исследования. 2021. № 2. C. 16-28. DOI: $10.24866 / 1998-6785 / 2021-2 / 16-28$

For citation: Avilov R. S. The War Minister Aleksey N. Kuropatkin in Vladivostok Fortress in 1903 (using a new sources) // Ojkumena. Regional researches. 2021. № 2. P. 16-28. DOI: $10.24866 / 1998-6785 / 2021-2 / 16-28$ 